\title{
VLIV REGIONÁLNÍCH VARIANT ŠPANĚLŠTINY NA KVALITU SIMULTÁNNIIHO TLUMOČENÍ DO ČEŠTINY
}

\author{
ZUZANA BALOUNOVÁ
}

\begin{abstract}
The Impact of Spanish Regional Varieties on the Quality of Simultaneous Interpreting into Czech

This paper describes a study conducted as part of the diploma thesis The Impact of Spanish Regional Varieties on the Quality of Simultaneous Interpreting into Czech (2019). The aim of the study was to find whether interpreters make more omissions, additions, semantic errors, and delivery errors when interpreting from Latin American varieties of Spanish than when interpreting from standard European Spanish, as defined by the Royal Spanish Academy (RAE). Another goal was to find whether the expectations of different user groups regarding the quality of simultaneous interpreting differ or not. The theoretical part of this article presents the findings and conclusions of studies published by authors who address the quality of simultaneous interpreting. The research portion of this article describes an experiment conducted at the Institute of Translation Studies, Faculty of Arts, Charles University: five master's degree students of conference interpreting (Czech A, Spanish C) were asked to simultaneously interpret a speech pronounced by four native speakers - from Argentina, Peru, Mexico and northern Spain. The interpreted versions of the speech were evaluated based on an established quality assessment model. To get another source of data, the interpreters filled out a questionnaire, which included questions about their experience with Spanish regional varieties, as well as a subjective evaluation of the difficulty of the speech, the speakers' accent, and their own interpreting. Joining the study were ten more participants - five general users and five student-users (3rd year undergraduate students of Spanish for Intercultural Communication), who were asked to assess the renditions in Czech. The last chapter of the article presents the results of the experiment, as well as the results of the questionnaire regarding quality assessment.
\end{abstract}

Keywords: quality in interpreting; quality assessment; simultaneous interpreting; standard Spanish; varieties of Spanish; interpreting errors 


\section{Úvod}

Cílem článku je popsat výzkum provedený pro potřeby diplomové práce Vliv regionálních variant španělštiny na kvalitu simultánního tlumočení do češtiny obhájené v květnu 2019 na Ústavu translatologie FF UK. Při výběru tématu výzkumu jsme vycházeli z požadavku, aby současný výzkum v oblasti tlumočení reflektoval sociokulturní a technologické změny, kterých jsme v dnešním globalizovaném světě svědky (Pöchhacker 2004: 200).

Geografická oblast, v níž se hovoři španělsky, je velmi rozsáhlá. Na celém světě hovoří španělsky více než půl miliardy osob, přičemž téměř 480 milionů z nich jsou rodilí mluvčí. Více než 90 procent pochází z Latinské Ameriky. Podle údajů Českého statistického úřadu bylo na konci roku 2017 (údaje $\mathrm{k} 31$. prosinci) v České republice evidováno celkem 4325 cizinců, včetně azylantů, pocházejících ze zemí, ve kterých je španělština oficiálním jazykem. ${ }^{1}$ Zhruba jedna třetina z nich pochází ze Španělska, zbylé dvě třetiny ze Střední či Jižní Ameriky. Tlumočníci s pracovními jazyky čeština a španělština se tudíž při práci setkávají s rodilými mluvčími různých variant španělštiny, navíc lze předpokládat, že komunitní tlumočníci se setkávají s rodilými mluvčími americké španělštiny častěji než s př́íchozími ze Španělska.

Přesto se studenti tlumočnictví během svého studia, at už na seminárích, nebo v rámci samostudia, setkávají ve větší míře s rodilými mluvčími evropské španělštiny. Studenti tlumočnictví by se měli seznámit $s$ co nejpestřejší škálou řečníků, a naučit se tak uplatňovat strategie a taktiky, které jim pomohou zabránit přetižení procesní kapacity a které zlepší kvalitu jejich tlumočnického výkonu.

Výzkum popsaný v tomto článku si kladl za cíl zjistit, zda je tlumočení rozdílných výslovnostních variant pro studenty tlumočnictví problematické, do jaké míry jsou studenti s různými variantami španělštiny seznámeni, jak často se s nimi setkávají a zda se může jejich zkušenost s konkrétními variantami španělštiny odrazit na kvalitě simultánního tlumočení do češtiny. Aby bylo hodnocení kvality tlumočnických výkonů co nejkomplexnější, byli do výzkumu zapojeni posluchači, jejichž úkolem bylo posoudit kvalitu tlumočení. Předmětem našeho zájmu byly dále nároky př́ijemců, konkrétně zda se liší způsob, jakým tlumočnické výkony hodnotí příjemci, kteří mají zkušenost s tlumočením, a př́ijemci, kteří takovou zkušenost nemají, a zda mají př́ijemci obecně při posuzování kvality simultánního tlumočení odlišné nároky než samotní tlumočníci.

\section{Teoretická východiska výzkumu}

Posuzování kvality tlumočnického výkonu může být velmi relativní, a proto musí být nahližzeno z různých hledisek a zkoumáno pomocí různých metod (Pöchhacker 2004: 153). Při hodnocení kvality je důležité posuzovat všechny složky tlumočnického výkonu, tedy výsledný produkt včetně tlumočníkova přednesu, dále věrnost tlumočení vůči výchozímu sdělení, komunikační účinek a plnění tlumočnické role. Zatímco v překladu se kvalita tradičně zaměřuje na aspekt věrnosti v opozici k aspektu volnosti, kterou

1 Český statistický úřad. Cizinci v ČR - včetně azylantů. Dostupné z: https://www.czso.cz/csu/cizinci /cizinci-v-cr-vcetne-azylantu (access: 18. 4. 2019). 
zaujímá text v cílovém jazyce $\mathrm{k}$ textu v jazyce výchozím, v tlumočení panuje konsenzus, podle kterého by měl tlumočník zachovat v první řadě smysl původního projevu spíše než jednotlivá slova (Kalina 2002: 121). Tento princip ovšem naráží na pestrost tlumočnické profese, kdy si např́klad soudní tlumočník při převodu nemůže dovolit tolik volnosti jako tlumočník pracující pro média. Kvalita proto nemůže být posuzována pouze na základě zachování smyslu původního projevu. ${ }^{2}$

Vypracovat model hodnocení kvality simultánního tlumočení se jako jeden z prvních pokusil Henri Barik (1971), který porovnával transkripce projevů ve výchozím a v cílovém jazyce a tlumočnický výkon hodnotil na základě počtu přidaných, vynechaných a chybně převedených informací. Barikovu typologii odchýlení od výchozího textu následně přejal a upravil Andrzej Kopczyński (1980), který se kromě výše uvedených přidaných, vynechaných a chybně převedených informací zaměřil na chyby přednesu, čímž do určité míry doplnil kritizovanou mezeru Barikovy typologie. Mezi chyby přednesu řadí Kopczyński (1980: 82) veškeré vysledovatelné chyby, které narušují plynulost tlumočení, konkrétně falešné začátky, zadrhávání, opakování a hezitace.

Obdobné hledisko k posuzování kvality tlumočení zaujímá Daniel Gile (2009), který usiluje o komplexní hodnocení kvality, při kterém jsou posuzovány dva spolu související aspekty tlumočnického výkonu - obsah a přednes. Pokud totiž není tlumočníkův přednes na dobré úrovni, trpí tím i obsah tlumočení. Naopak správný přednes a př́jemný tón hlasu mohou úroveň tlumočení pozvednout $\mathrm{v}$ případě, že tlumočení zaostává po obsahové stránce (Gile 2009: 38). Hodnocení kvality tudíž nemusí nutně souhlasit se správností převodu informací z výchozího do cílového jazyka. Mnohdy mohou posluchači označit jako velmi dobré takové tlumočení, které sice obsahuje řadu významových posunů a ztrát, ale které bylo proneseno sebevědomě a př́ijemným tónem. Naopak začínající tlumočníci, na jejichž hlase je mnohdy znát nervozita a nejistota, mohou být posluchači hodnoceni hůře, přestože se v jejich převodu vyskytuje menší počet významových posunů a obsahových ztrát.

Podle Gila se hodnocení kvality simultánního tlumočení odvíjí od skutečnosti, kdo tuto kvalitu posuzuje. Gile (2009: 40) rozlišuje mezi čtyřmi účastníky komunikační situace a zároveň hodnotiteli kvality tlumočení, jmenovitě mezi osobami vysilatele, př́jemce, zadavatele a tlumočníka. Pro potřeby výzkumu popsaného v tomto článku jsou stěžejní př́ijemce a tlumočník. Př́ijemce simultánního tlumočení posuzuje kvalitu tlumočnického výkonu zejména na základě srozumitelnosti, jazykové přijatelnosti, terminologické přesnosti a logické návaznosti. Př́jemce většinou není schopen posoudit obsahovou přesnost a věrnost vůči originálu, který neslyšel, výjimkou mohou být pouze situace, kdy se tlumočník při převodu dopouští výrazných chyb či významových posunů. Tlumočník se při převodu stává jak posluchačem, tak vysilatelem, ovládá velmi dobře oba jazyky komunikační situace, lze však předpokládat, že má nižší znalost tématu, terminologie a účelu komunikace než ostatní účastníci. Tlumočníkova procesní kapacita je navíc během samotného procesu simultánního tlumočení natolik zatížena (nemluvě o případech, kdy je přetížena), že není v jeho silách kvalitu svého výkonu plně posoudit.

2 V této kapitole se dále soustředíme na posuzování kvality simultánního tlumočení, byt’ se kritéria hodnocení kvality simultánního a konsekutivního tlumočení do určité míry překrývají. 
Otázce posuzování kvality tlumočení profesionálním tlumočníkem, o které hovoří Gile, byl věnován výzkum, který provedla Hildegund Bühlerová v roce $1986 .{ }^{3}$ Účelem tohoto výzkumu, který se opíral o metodu dotazníkového šetření, bylo zjistit, jaká jsou očekávání a nároky profesionálních tlumočníků na kvalitu tlumočení. Dotazníky obsahovaly seznam šestnácti kritérií hodnocení kvality tlumočení, která měli respondenti ohodnotit podle stupně důležitosti jako velmi důležitá, důležitá, méně důležitá či nedůležitá. Většinu kritérií respondenti ohodnotili jako důležitou. Výsledky tohoto výzkumu, kterého se zúčastnili pouze profesionální tlumočníci, Bühlerová zobecnila na všechny potenciální př́ijemce tlumočení. Toto zobecnění však bylo chápáno jako problematické, a proto provedla v roce 1989 obdobný výzkum Ingrid Kurzová, která se zaměřila na očekávání a nároky účastníků konference neboli netlumočníků. ${ }^{4}$ Kurzová opět pracovala s metodou dotazníkového šetření, do kterého zařadila pouze osm z šestnácti kritérií navržených Bühlerovou, konkrétně rodilý přízvuk, př́jemný hlas, plynulý přednes, logickou návaznost, zachování smyslu výchozího projevu, úplnost a gramatickou a terminologickou správnost. Zatímco profesionální tlumočníci ohodnotili většinu kritérií jako důležitou, netlumočníci takto ohodnotili pouze kritérium logické návaznosti, terminologické správnosti a zachování smyslu výchozího projevu. Ostatní kritéria ohodnotili jako méně důležitá. Pro zajímavost lze zmínit další výzkum provedený v roce 1995 Ingrid Kurzovou a Franzem Pöchhackerem (Pöchhacker 2004: 154), z něhož vyplynulo, že př́ijemci tlumočení přikládají větší důležitost příjemnému hlasu, rodilému přízvuku a plynulému projevu než úplnosti tlumočení.

Obdobný výzkum provedla dále například Ángela Colladosová Aísová (2008). Z díla Colladosové Aísové bychom rádi stručně okomentovali studie, ve kterých se věnovala otázce intonace, konkrétně tomu, do jaké míry může tlumočníkův hlas a intonace ovlivnit hodnocení kvality tlumočení. Z výsledků studií vyplynulo, že monotónní intonace ovlivní celkové vnímání tlumočníkova výkonu negativně a že posluchači takového tlumočníka vnímají spíše jako méně důvěryhodného a méně profesionálního. ${ }^{5}$

V závěru této části bychom rádi stručně zmínili otázku vnějších faktorů neboli vstupních proměnných, které ovlivňují kvalitu tlumočení. Mezi tyto proměnné řadí Pöchhacker (2004: 126) zvukovou kvalitu výchozího projevu, vizuální kontakt, řečníkovu výslovnost, prozódii a intonaci, rychlost a způsob řečníkova přednesu a podobu tlumočeného projevu, konkrétně jeho lexikální a obsahovou složku. Tyto proměnné byly zohledněny při prrípravě experimentu popsaného na následujících stranách.

3 Bühler, Hildegund (1986) 'Linguistic (semantic) and extra-linguistic (pragmatic) criteria for the evaluation of conference intepretation and interpreters', Multilingua 5(4): 231-235.

4 Kurz, Ingrid (1989) 'Conference interpretation: Expectations of different user groups', in Franz Pöchhacker - Miriam Schlesinger (eds.) The Interpreting studies reader, Abingdon: Routledge, 312-324.

5 Collados Aís, Ángela (2017) 'La entonación monótona y la calidad de la interpretación simultánea: frecuencia, conceptualizaciones y efectos', Meta 61(3): 675-691. 


\section{Metodologie výzkumu a sběr dat}

Na základě cílů výzkumu popsaných v úvodu článku jsme zformulovali následující výzkumné otázky:

1. Dochází při simultánním tlumočení amerických variant španělštiny $\mathrm{k}$ častějším odchýlením od výchozího projevu a chybám přednesu, a tudíž k nižší kvalitě tlumočení?

2. Mají tlumočníci při posuzování kvality simultánního tlumočení odlišná očekávání než jejich prŕijemci?

První z výzkumných otázek zohledňuje zejména objektivní hodnocení tlumočnických výkonů založené na aplikaci typologie odchýlení od výchozího texu. ${ }^{6}$ Naopak druhá výzkumná otázka zohledňuje zejména subjektivní hodnocení tlumočnických výkonů, při formulování odpovědi budeme vycházet především z dotazníkového šetření.

Sběr dat byl realizován pomocí experimentu, kterého se zúčastnilo pět studentů druhého a třetího ročníku navazujícího magisterského oboru Tlumočnictví: čeština-španělština na Ústavu translatologie FF UK, a dále pomocí dotazníkového šetření, kterého se zúčastnily celkem tři skupiny respondentů, kromě výše uvedených studentů magisterského programu také studenti bakalářského oboru Španělština pro mezikulturní komunikaci na Ústavu translatologie FF UK, a nakonec př́jemci, kteří se tlumočení nevěnují a nemají prakticky žádnou zkušenost s tlumočením, případně pouze minimální z médií či z konferencí.

Během experimentu studenti magisterského programu simultánně tlumočili nahrávku uceleného projevu rozděleného do čtyř částí o podobné délce a obsahové náročnosti. ${ }^{7}$ Každá z částí byla namluvena jinou řečnicí, konkrétně se jednalo o mluvčí z Argentiny (Buenos Aires), z Peru (Trujillo, region La Libertad), ze Španělska (Vitoria-Gasteiz, provincie Álava) a z Mexika (Celaya, stát Guanajuato). Při výběru řečnic z Latinské Ameriky bylo zohledněno, nakolik je pravděpodobné, že se tlumočníci s konkrétní výslovnostní variantou setkají na českém trhu. ${ }^{8}$ Při výběru rodilé mluvčí ze Španělska byl kladen důraz na to, aby pocházela $z$ oblasti, kde se uplatňuje spisovná varianta španělštiny podle Španělské královské akademie (RAE). Mezi tyto oblasti jsou řazeny provincie, které se nacházejí na sever od Madridu, např́íklad provincie Burgos, La Rioja, Valladolid, Palencia či

6 Za tímto účelem byla použita typologie odchýlení od výchozího textu, kterou vypracoval Henri Barik (1971). Pro potřeby našeho výzkumu byl omezen počet rozlišovaných podkategorií, některé z podkategorií byly sloučeny tak, jak navrhuje Andrzej Kopczyński (1980: 69). V kategorii vynechaných informací rozlišujeme na základě závažnosti obsahové ztráty mezi podkategoriemi M1, M2 a M4, přičemž do podkategorie M4 řadíme značné obsahové ztráty způsobující výrazný významový posun. Dále rozlišujeme přidané informace $\mathrm{A} 1$ a $\mathrm{A} 3$, opět na základě závažnosti významového posunu. V kategorii sémantických chyb rozlišujeme méně závažné chyby a nepřesnosti E1, závažnější sémantické chyby E2 a závažné chyby E5, které výrazně posouvají smysl původního sdělení. Typologie byla doplněna o kategorii chyb přednesu zavedenou Kopczyńskim (1980: 82).

7 Při př́ipravě projevu bylo zvoleno téma obecnějšího rázu, které není terminologicky př́liš náročné během experimentu byl tlumočen projev Káva a její pozitivní vliv na lidské zdraví.

8 Uvědomujeme si, že vybrané varianty nemusejí vypovídat o celkové problematice tlumočení regionálních variant španělštiny, kterých je velmi mnoho, avšak maximální možný počet variant, na které se výzkum zaměří, byl kvůli povaze výzkumu od začátku omezen. Zároveň je důležité zmínit, že přestože dnešní hranice států nebývají současně hranicemi jednotlivých výslovnostních variant (Čermák 2005: 107), literatura věnovaná španělské fonetice o výslovnostních rysech hovoří z důvodu větší přehlednosti zejména ve spojení s jednotlivými státy. 
Álava. Všem řečnicím bylo umožněno, aby do svých částí námi připraveného projevu zanesly lexikální změny a projev upravily tak, aby byl přirozený pro variantu španělštiny, jakou samy používají. V závěru předchozí kapitoly byly vyjmenovány vnější proměnné ovlivňující kvalitu simultánního tlumočení. Pro potřeby našeho výzkumu bylo stěžejní snížit počet nezávislých proměnných, které by mohly ovlivnit námi měřené proměnné. Z toho důvodu byl zohledněn počet číselných údajů, vlastních jmen či odborných termínů, který se v jednotlivých částech projevu vyskytuje, a také byla kontrolována rychlost přednesu každé části projevu, která se pohybuje v rozmezí 107 až 112 slov za minutu. ${ }^{9}$ Ve snaze snížit počet nezávislých proměnných jsme se dále rozhodli oslovit pouze ženy; stř́idání ženských a mužských hlasů by totiž mohlo představovat zbytečně větší zátěž na procesní kapacitu tlumočníků a mohlo by zkreslit výsledky experimentu.

Dále byla použita metoda dotazníkového šetření, konkrétně byly vypracovány tři odlišné dotazníky, přičemž první z nich byl určen skupině tlumočníků a kromě dojmů z tlumočeného projevu a vlastního tlumočnického výkonu zjištoval dosavadní zkušenost tlumočníků s poslechem/tlumočením odlišných regionálních variant španělštiny. Zbylé dva dotazníky byly určené dvěma výše popsaným skupinám př́jemců. Ti v dotaznících hodnotili kvalitu tlumočnických výkonů, každý z př́ijemců poslouchal a následně hodnotil pouze jeden tlumočnický výkon.

\section{Vliv regionálních variant španělštiny na kvalitu simultánního tlumočení do češtiny}

Na následujících stranách se pokusíme nalézt odpovědi na výzkumné otázky představené v úvodu předchozího oddílu. V odpovědi na otázku, zda dochází při simultánním tlumočení amerických variant španělštiny k častějším odchýlením od výchozího projevu a chybám přednesu, a tudíž k nižší kvalitě tlumočení, lze konstatovat, že různé výslovnostní varianty španělštiny skutečně ovlivňují počet odchýlení od výchozího projevu a chyb přednesu, jakého se tlumočníci při simultánním tlumočení do češtiny dopouštějí. ${ }^{10}$

Pokud přihlédneme k počtu odchýlení od výchozího projevu a chyb přednesu, kterého se tlumočníci dopustili v jednotlivých částech projevu souhrnně, lze konstatovat, že se nejvíce odchylovali od originálu a nejčastěji chybovali ve druhé části namluvené mluvčí z Peru. Naopak nejméně se odchylovali od originálu a chybovali při převodu třetí části namluvené mluvčí ze Španělska. Tuto část převedli tlumočníci obsahově nejpřesněji a s ohledem na původní sdělení nejvěrněji. ${ }^{11}$ Zároveň jsme v této části zaznamenali nej-

9 Př́lišs pomalý nebo př́liš rychlý přednes mohou vést ke zhoršené kvalitě tlumočnického výkonu (Čeňková 2008: 41). Za ideální rychlost přednesu projevu ve výchozím jazyce proto Mezinárodní asociace konferenčních tlumočníků (AIIC) považuje rychlost 100-120 slov za minutu. Toto rozmezí potvrdil ve své studii z roku 1969 David Gerver, který označil za ideální rychlost projevu ve výchozím jazyce rychlost o 95-120 slovech za minutu (Pöchhacker 2004: 129).

10 Pro potřeby této kapitoly je stěžejní pořadí jednotlivých částí projevu. První část projevu byla namluvena rodilou mluvčí z Argentiny, druhá část mluvčí z Peru, třetí část mluvčí ze Španělska a čtvrtá část mluvčí z Mexika.

11 Zde uvádíme souhrnný počet odchýlení od výchozího projevu (na základě závažnosti významového posunu) a chyb přednesu. Počet odchýlení typu M1, A1, A3, E1: 1. část - 35, 2. část - 49, 3. část - 30, 


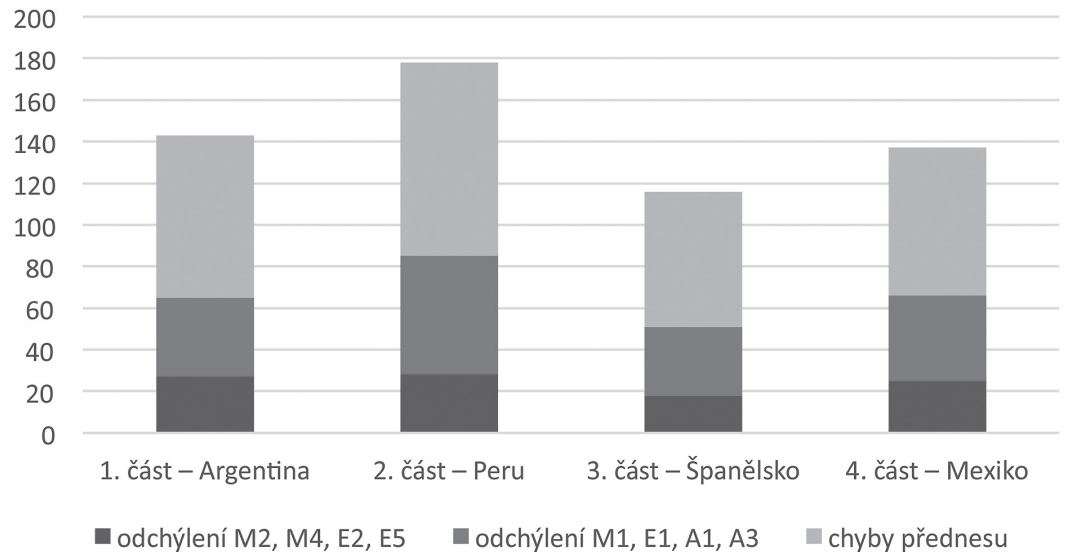

Graf 1. Počet odchýlení od výchozího projevu a chyb přednesu - souhrnně

nižší počet chyb přednesu. V prŕípadě první a čtvrté části namluvené mluvčími z Argentiny a $\mathrm{z}$ Mexika lze hovořit o víceméně vyrovnaném počtu odchýlení od výchozího projevu a chyb přednesu.

Pokud usouvztažníme výše uvedené výsledky s odpověd’mi tlumočníků na otázku „Jak byste ohodnotil/a jednotlivé části projevu z hlediska obtížnosti porozumět mluvčím?“, zjistíme, že tlumočníci ohodnotili v průměru jako nejobtížnější první část namluvenou mluvčí z Argentiny, nikoliv druhou část, v níž se odchylovali od originálu a chybovali častěji. Naopak je velmi zajímavé, že pouze jeden tlumočník ohodnotil z hlediska obtížnosti porozumět mluvčí za nejnáročnější tu část, v níž jsme u něj zaznamenali nejvyšší počet odchýlení a chyb přednesu. Naopak dva tlumočníci ohodnotili část, ve které se dopustili nejvyššího počtu odchýlení a chyb přednesu, dokonce za nejsnazší. Tyto výsledky podle našeho názoru potvrzují, že tlumočníkova procesní kapacita je při simultánním tlumočení natolik zatížena, že není v jeho silách plně posoudit kvalitu svého výkonu, potažmo povahu tlumočeného projevu (Gile 2009: 42). Přestože ohodnotili tlumočníci první část z hlediska obtížnosti porozumět mluvčí za nejobtížnější, čtyři z celkem pěti tlumočníků v odpovědi na otázku „Dokážete na základě přízvuku jednotlivých mluvčích odhadnout, ze které země pocházejí?" správně uhodli, že tato mluvčí pochází z Argentiny. U mluvčí ze Španělska měli správný odhad dva tlumočníci, u mluvčí z Mexika pouze jeden tlumočník a u mluvčí z Peru žádný.

Za pozornost stojí také skutečnost, že čtyři tlumočníci ohodnotili projev celkově jako poměrně snadný, pouze jeden tlumočník jako poměrně obtížný. Tlumočník č. 1, který ohodnotil projev jako poměrně obtížný, se však ze všech tlumočníků dopustil zdaleka nejnižšího počtu odchýlení i chyb přednesu. ${ }^{12}$

4. část -29 . Počet odchýlení typu M2, M4, E2, E5: 1. část $-27,2$. část -28 , 3. část -18 , 4. část -25. Počet chyb přednesu: 1 . část $-78,2$. část $-93,3$. část $-65,4$. část -71 .

12 Pro přehlednost odkazujeme na tlumočníky číslem odpovídajícím pořadí, které odvozujeme od počtu odchýlení od výchozího projevu a chyb přednesu, tlumočník č. 1 se dopustil v porovnání s ostatními tlumočníky nejnižšího počtu odchýlení a chyb přednesu. 
$\mathrm{Na}$ tomto místě bychom se rádi věnovali odpovědím na otázky, jejichž cílem bylo zjistit, do jaké míry jsou tlumočníci s jednotlivými variantami španělštiny seznámeni a jak často se s nimi setkávají. ${ }^{13}$ Zatímco rodilé mluvčí evropské španělštiny tlumočí souhrnně často, rodilé mluvčí americké španělštiny tlumočí souhrnně spíše výjimečně. Co se poslechu jednotlivých variant v médiích (TV, rádio) týče, odpovědi se lišily méně, četnost, $s$ jakou poslouchají obě varianty, je víceméně totožná, ovšem tlumočníci č. 1 a 2 , kteři jako jediní uvedli, že rodilé mluvčí americké španělštiny poslouchají v médiích často, se při převodu dopustili nejnižšího počtu odchýlení od výchozího projevu a chyb přednesu. Zbylí tlumočníci v této odpovědi uvedli, že rodilé mluvčí americké španělštiny poslouchají v médiích pouze výjimečně, př́ípadně vůbec.

Dále tlumočníci odpovídali na otázku, zda při tlumočení preferují rodilé mluvčí evropské, nebo americké španělštiny, př́ípadně zda nemají preferenci. Jistě stojí za pozornost skutečnost, že žádnou preferenci nemá tlumočník č. 1 a preferenci americké španělštiny uvedl tlumočník č. 2, u kterého se vyskytl druhý nejnižší počet odchýlení i chyb přednesu, a tlumočník č. 5, jehož výkon byl ve všech částech projevu jako u jediného vyrovnaný. ${ }^{14}$ Zbylí dva tlumočníci uvedli preferenci evropské španělštiny.

$\mathrm{Na}$ základě výše uvedeného usouvztažnění jednotlivých tlumočnických výkonů s odpověd’mi $\mathrm{v}$ dotaznících lze předpokládat, že pokud by se s rodilými mluvčími americké španělštiny setkávali studenti nejen při tlumočení stejně často jako s rodilými mluvčími evropské španělštiny, při převodu by se dopouštěli nižšího počtu odchýlení od originálu a chyb př̀ednesu.

\section{Nároky příjemců na kvalitu simultánního tlumočení}

Při formulování otázky, zda mají tlumočníci při posuzování kvality simultánního tlumočení odlišná očekávání než jejich příjemci, jsme vycházeli z předchozích výzkumů uskutečněných Hildegund Bühlerovou (1986), Ingrid Kurzovou (1989) a Ángelou Colladosovou Aísovou (2008). Po přihlédnutí k odpovědím získaným prostřednictvím dotazníkového šetření lze konstatovat, že námi získané výsledky odpovídají výsledkům výše uvedených výzkumů.

Z odpovědí uvedených v dotaznících vyplývá, že nejméně kritičtí jsou při hodnocení tlumočení př́ijemci netlumočníci. Tuto skupinu tvořili vysokoškolsky vzdělaní respondenti, absolventi nefilologických oborů. Tito př́ijemci hodnotili tlumočnické výkony převážně jako nadprůměrné, občas jako vynikající. Druhá skupina př́ijemců tvořená studenty bakalářského oboru Španělština pro mezikulturní komunikaci byla při hodnocení tlumočnických výkonů kritičtější, tlumočení hodnotila převážně jako průměrné,

13 Tlumočníci odpovídali na následující otázky: Jak často tlumočíte rodilé mluvčí evropské španělštiny? Jak často tlumočíte rodilé mluvčí americké španělštiny? Jak často posloucháte (TV, rádio) rodilé mluvčí evropské španělštiny? Jak často posloucháte (TV, rádio) rodilé mluvčí americké španělštiny? Jedná se o uzavřené výběrové otázky, na které respondenti odpovídali výběrem z těchto možností: velmi často, často, občas, výjimečně, nikdy.

14 Tlumočník č. 5 se v 1 . části dopustil celkem 30 odchýlení od výchozího projevu a chyb přednesu, ve 2. a ve 3. části 31 odchýlení a chyb a ve 4 . části 34 odchýlení a chyb. 


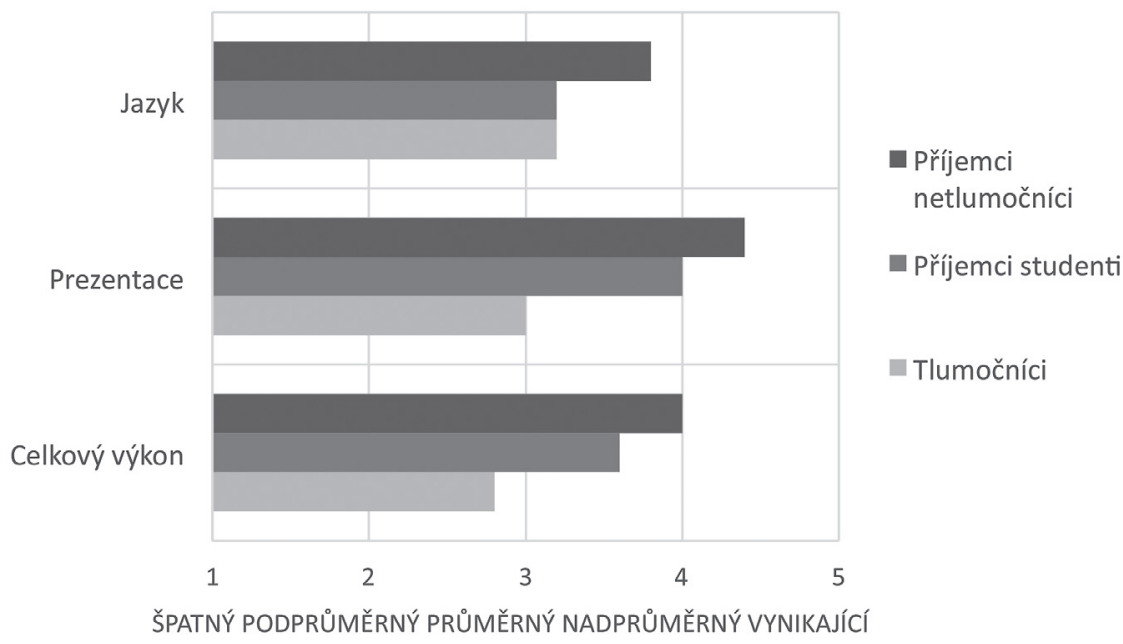

Graf 2. Průměrné hodnocení kvality tlumočnických výkonů

občas jako nadprůměrné a výjimečně jako vynikající. ${ }^{15}$ Nejkritičtější byli při hodnocení tlumočnických výkonů samotní tlumočníci, kteří svůj výkon hodnotili převážně jako průměrný, př́ipadně podprůměrný a výjimečně jako nadprůměrný.

Největší rozdíl mezi odpověd’mi lze vypozorovat v dotaznících věnovaných hodnocení výkonu tlumočníka č. 2. Zatímco tlumočník ohodnotil svůj výkon celkově jako podprůměrný, př́ijemce student jej v tomto směru ohodnotil jako nadprůměrný a př́ijemce netlumočník jako vynikající. Z jazykového hlediska ohodnotil tlumočník svůj výkon jako průměrný, oba př́ijemci jako nadprůměrný. Z hlediska prezentace ohodnotil tlumočník svůj výkon jako podprůměrný, oba př́iemci jako vynikající. Domníváme se, že rozdílné hodnocení kvality tohoto výkonu mohla do určité míry ovlivnit skutečnost, že přijemci neslyšeli originál, a proto nebyli schopni posoudit obsahovou přesnost tlumočení. Tlumočník č. 2 se oproti ostatním tlumočníkům dopustil spíše nižšího počtu sémantických chyb a chyb přednesu, které jsou př́ijemci vysledovatelné a narušují plynulost tlumočení, tedy nepřirozených či nesprávných výrazů, falešných začátků, přeřeků, opakování a hezitací. Tlumočník č. 2 však velmi často vynechával, v jeho tlumočení jsme zaznamenali celkem 43 vynechání (pro srovnání, u tlumočníka č. 1 pouze 21 vynechání). Přesto působilo tlumočení plynule a nevyskytly se v něm například přiliš dlouhé pauzy, které by př́ijemce na vynechání upozornily. Jedním z důvodů může být skutečnost, že se jedná o tlumočníka, který měl v době provedení experimentu v porovnání s ostatními tlumočníky největší zkušenost se simultánním tlumočením (vyšší počet odchozených seminářù), lze tedy předpokládat, že si již osvojil tlumočnické strategie a svůj výstup má lépe pod kontrolou.

15 Lze předpokládat, že pokud bychom oslovili studenty vyššího ročníku, př́ípadně profesionální tlumočníky, získali bychom odlišné výsledky. Studenti bakalářského programu mohou být shovívavější, jelikož se sami připravují na tlumočnickou kariéru a mohou se obávat, nakolik budou v budoucnu sami schopni simultánně tlumočit. 
Naopak nejmenší rozdíl mezi vlastním hodnocením tlumočení a hodnoceními př́ijemců lze vypozorovat v dotaznících věnovaných výkonu tlumočníka č. 4 . Tento výkon byl všemi třemi respondenty ohodnocen jako průměrný, konkrétní odpovědi se lišily pouze minimálně. Tlumočník č. 4 se dopustil ve srovnání s ostatními tlumočníky průměrného počtu odchýlení od originálu, $\mathrm{v}$ jeho převodu se však vyskytl nejvyšší počet chyb přednesu, př́ijemce student $\mathrm{v}$ dotazníku $\mathrm{v}$ dodatečném komentáři uvedl, že byl projev srozumitelný, ale trhaný, tlumočník často začínal jednu větu vícekrát a v jeho tlumočení se objevily přeřeky.

Tyto poznatky potvrzují, jak neoddělitelně spolu při hodnocení kvality tlumočení souvisejí obsah a přednes. Jak bylo uvedeno v kapitole věnované teoretickým východiskům výzkumu, hodnocení kvality nutně nesouhlasí se správností převodu informací a příjemci mohou mnohdy za velmi kvalitní tlumočení označit takový převod, který obsahuje řadu významových posunů a ztrát, ale který byl pronesen sebevědomě a př́jemným tónem (Gile 2009: 38).

Pokud usouvztažníme výsledky uvedené v odpovědi na první výzkumnou otázku, tedy počet odchýlení od výchozího projevu a chyb přednesu, s odpověd’mi příjemců, kteří měli v rámci dotazníků ohodnotit, která část tlumočení byla nejpovedenější či naopak méně povedená než zbylé části, zjistíme, že tyto odpovědi se pouze výjimečně shodují s objektivními výsledky experimentu neboli s počtem odchýlení od výchozího projevu a chyb přednesu. Důvodem může být např́klad to, že př́jemci neznalí originálu posuzují kvalitu simultánního tlumočení zejména na základě srozumitelnosti, jazykové přijatelnosti, terminologické přesnosti a logické návaznosti (Gile 2009: 39), nikoliv na základě obsahové přesnosti a věrnosti tlumočení vůči originálu. Tlumočený projev však nebyl terminologicky příliš náročný, pokud by byl projev odbornějšího rázu, obsahoval více specializované terminologie a mezi př́ijemci by byli odborníci na dané téma, lze předpokládat, že bychom prostřednictvím dotazníkového šetření získali odlišné výsledky. Přesto se domníváme, že výzkum popsaný v tomto článku může sloužit jako pilotní studie pro další výzkumy v této či podobné oblasti

\section{Závěr}

Účelem výzkumu popsaného v tomto článku bylo zjistit, nakolik jsou studenti tlumočnictví seznámeni s různými výslovnostními variantami španělštiny a zda může být jejich tlumočnický výkon na základě této zkušenosti kvalitnější. Přestože nelze zejména $\mathrm{z}$ důvodu nízkého počtu účastníků experimentu námi získané výsledky zobecňovat, z výsledků výzkumu vyplývá, že převod části projevu namluvené mluvčí ze Španělska byl obsahově nejpřesnější a tlumočníci během něj chybovali méně často než v ostatních částech projevu. Zároveň lze konstatovat, že nejmenšího počtu odchýlení od originálu a chyb přednesu se ve zbylých částech projevu dopustili tlumočníci, kteř́ jsou v kontaktu s americkými variantami španělštiny (zejména prostřednictvím médií, tedy televize či rádia) častěji než ostatní tlumočníci. Naopak tlumočníci, kteří jsou v tomto směru $\mathrm{s}$ americkou španělštinou $\mathrm{v}$ kontaktu pouze výjimečně, případně vůbec, se dopustili nejvyššího počtu odchýlení a chyb, jejich tlumočení lze tudíž považovat za nejméně kvalitní. 
Domníváme se, že vzhledem k potřebám tlumočníků, jejichž pracovními jazyky jsou čeština a španělština, je žádoucí, aby byli studenti tlumočnictví během výuky i během samostudia vystaveni rozdílným výslovnostním variantám španělštiny. S ohledem na moderní technologie, online přenosy televizních stanic a databáze projevů mají studenti v současné době mnoho možností, jak mohou být s různými regionálními variantami španělštiny v kontaktu.

\section{BIBLIOGRAFIE}

Balounová, Zuzana (2019) Vliv regionálních variant španělštiny na kvalitu simultánního tlumočení do češtiny, Praha: Univerzita Karlova.

Barik, Henri (1971) 'A Description of Various Types of Omissions, Additions and Errors of Translation Encountered in Simultaneous Interpretation', Meta 16(4): 199-210.

Bühler, Hildegund (1985) 'Conference Interpreting. A Multichannel Communication Phenomenon', Meta 30(1): 49-54.

Bühler, Hildegund (1986) 'Linguistic (semantic) and extra-linguistic (pragmatic) criteria for the evaluation of conference interpretation and interpreters', Multilingua 5(4): 231-235.

Collados Aís, Ángela (2008) 'Evaluación de la calidad en interpretación simultánea: Contrastes de exposición e inferencias emocionales. Evaluación de la evaluación’, in Gyde Hansen - Andrew Chesterman - Heidrun Gerzymisch-Arbogast (eds.) Efforts and models in interpreting and translation research: a tribute to Daniel Gile, Amsterdam: John Benjamins, 193-214.

Collados Aís, Ángela (2017) 'La entonación monótona y la calidad de la interpretación simultánea: frecuencia, conceptualizaciones y efectos', Meta 61(3): 675-691.

Čeňková, Ivana (2001) Teorie a didaktika tlumočení I, Praha: Univerzita Karlova, Filozofická fakulta.

Čeňková, Ivana (2008) Úvod do teorie tlumočení, Praha: Česká komora tlumočníkủ znakového jazyka.

Čermák, Petr (2005) Fonetika a fonologie současné španělštiny, Praha: Karolinum.

Gerver, David (1969) 'The Effects of Source Language Presentation Rate on the Performance of Simultaneous Conference Interpreters', in Franz Pöchhacker - Miriam Shlesinger (eds.) The interpreting studies reader. London: Routledge, 53-66.

Gile, Daniel (2009) Basic concepts and models for interpreter and translator training, Amsterdam: John Benjamins.

Hale, Sandra - Napier, Jemina (2013) Research methods in interpreting: a practical resource, London: Bloomsbury.

Jones, Roderick (2002) Conference Interpreting Explained, Manchester: St. Jerome Publishing.

Kalina, Sylvia (2002) 'Quality in interpreting and its prerequisites', in Giuliana Garzone - Maurizio Viezzi (eds.) Interpreting in the 21st century: challenges and opportunities: selected papers from the 1st Forli conference on interpreting studies, Amsterdam: John Benjamins, 121-130.

Kopczyński, Andrzej (1980) Conference interpreting: some linguistic and communicative problems, Poznaň: Univerzita Adama Mickiewicze v Poznani.

Králová, Jana (1998) Kapitoly ze zvukového rozboru španělštiny (na pozadí češtiny), Praha: Karolinum.

Králová, Jana (2012) Vybrané problémy španělské stylistiky na pozadí češtiny, Praha: Univerzita Karlova, Filozofická fakulta.

Kurz, Ingrid (1989) 'Conference interpretation: Expectations of different user groups', in Franz Pöchhacker - Miriam Schlesinger (eds.) The Interpreting studies reader, Abingdon: Routledge, 312-324.

Kurz, Ingrid (2008) 'The impact of non-native English on students' interpreting performance' in Gyde Hansen - Andrew Chesterman - Heidrun Gerzymisch-Arbogast (eds.) Efforts and models in interpreting and translation research: a tribute to Daniel Gile, Amsterdam: John Benjamins, 179-192.

Pöchhacker, Franz (2004) Introducing interpreting studies, London: Routledge.

Pöchhacker, Franz (2002) 'Researching Interpreting Quality: Models and methods', in Giuliana Garzone - Maurizio Viezzi (eds.) Interpreting in the 21st century: challenges and opportunities: selected papers from the 1st Forli conference on interpreting studies, Amsterdam: John Benjamins, 95-106. 
Sochorová, Veronika (2018) Př́izvuk řečníka jako faktor ovlivňující kvalitu konsekutivního tlumočení: srovnání rodilých a nerodilých mluvčích, Praha: Univerzita Karlova.

\section{RESUMEN}

El español se convirtió en la segunda lengua más hablada en el mundo. Es la lengua materna para 470 millones de personas - más del $90 \%$ de las personas que tienen el español como lengua materna provienen de América Latina. Esto es solamente una de las razones por la cual los estudiantes de Intepretación checo-español deberían adquirir un sólido conocimiento de las variedades regionales del español. Para determinar el nivel del conocimiento de las variedades regionales del español entre los estudiantes de interpretación, se llevó a cabo un experimento con cinco estudiantes del programa de Interpretación checo-español en el Instituto de Traductología, Facultad de Filosofía y Letras, Universidad Carolina. Como parte del estudio, utilizamos la tipología de errores en interpretación propuesta por Henri Barik (1971) y elaborada por Andrzej Kopczyński (1980). Al experimento se le unieron diez participantes más (un grupo de usuarios en general y un grupo de estudiantes de traducción e interpretación) con el objetivo de comprobar que la evaluación de la calidad en interpretación simultánea varía entre distintos grupos de usuarios, tal y como lo indican las investigaciones realizadas por Ingrid Kurz (1986) o Ángela Collados Aís (2008). Los resultados demuestran, entre otro, que los intérpretes cometen menos errores y producen una versión más correcta cuando interpretan la parte hablada por la oradora de España que cuando interpretan las partes habladas por las oradoras de Argentina, de Perú o de México. Sin embargo, los participantes que suelen ver los programas de televisión de América Latina en la misma medida que los programas de España encuentran menos dificultades para interpretar las oradoras de América Latina. En cuanto a las expectativas de los usuarios, los resultados confirman que los diferentes grupos de usuarios no tienen las mismas expectativas; los intérpretes son los más críticos a la hora de evaluar sus propios rendimientos. Asimismo, los estudiantes de traducción e intepretación son más exigentes que los usuarios en general. Aunque el número de los participantes fue bastante limitado, el presente estudio pretende servir de un estudio piloto y ayudar a ampliar la investigación sobre la calidad en interpretación simultánea.

PhDr. Zuzana Balounová

Ústav translatologie, Filozofická fakulta, Univerzita Karlova

Zuzana.Balounova@seznam.cz 